\title{
PART TWO
}

The Kamoro in relation to the Asmat 


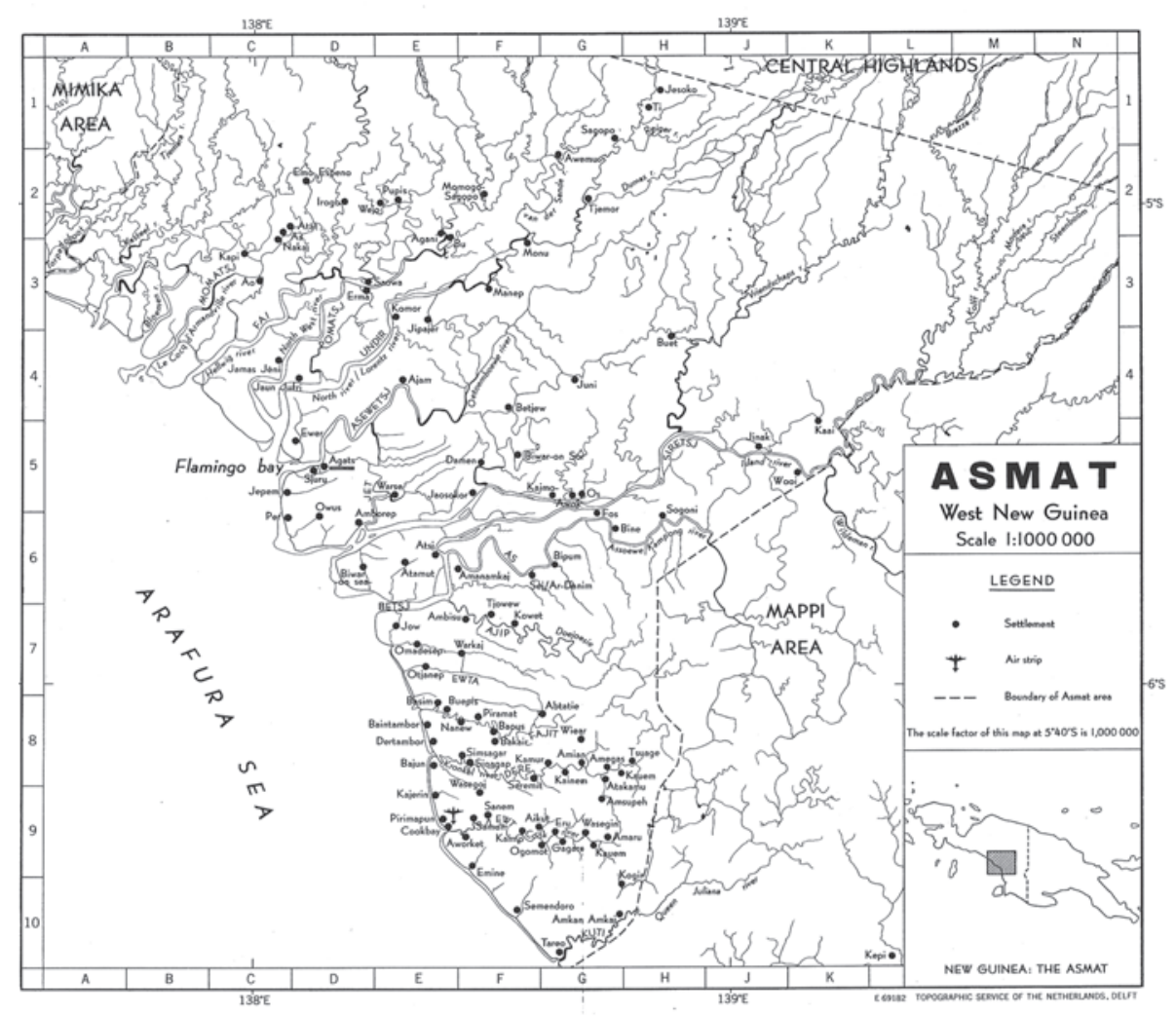

Map 3. Asmat in the 1960s. From Van der Schoot 1969: Appendix. 


\section{Chapter vi}

\section{The theory of comparison and the context of the rituals}

\section{The theory}

Observation entails comparing new information with information stored and systematized by the brain in a never-ending, always open-ended, dialectical process. Viewed in this way, 'raw data' and 'closure' are merely useful fictions. Most likely, the Kamoro information stored at present in my brain is not identical with information stored at the time of my observation in the 1950s and 1960s. The information has been extended since then, by new information (in particular from Zegwaard and Coenen) not readily available to me at the time, and also as a result of rethinking issues, theoretical concepts, methods and conclusions. No doubt there are incongruities and contradictions between the earlier and the later stores of information. Last but not least, the present book, as it now stands, could not have been written in the 1950s and 1960s.

These considerations call for a spelling out of the terms of cross-cultural analysis in use today. Any comparison is a construction or reconstruction, and any construction is meant to serve a particular purpose. So, what are my terms of comparison and what purpose do they serve? I tackle these issues by drawing on Knauft's comparison of South Coast New Guinea cultures, and on descriptions of these cultures by several other ethnographers in welldocumented, conventional monographs and accounts during a period of moderate colonization lasting till about the 1960s (Knauft 1993). Though the title of this chapter reflects current anthropological themes, and also since ethnography reflects the ethnographer's concern, ethnographic differences are not simply Western projections (Knauft 1993:10). One should not mistake the map for the territory. ${ }^{1}$ The territory of seven South Coast New Guinea culture areas, extending over some 2,500 kilometres, may justifiably be viewed as an ethnographic region, because the cultures share a number of salient features. 


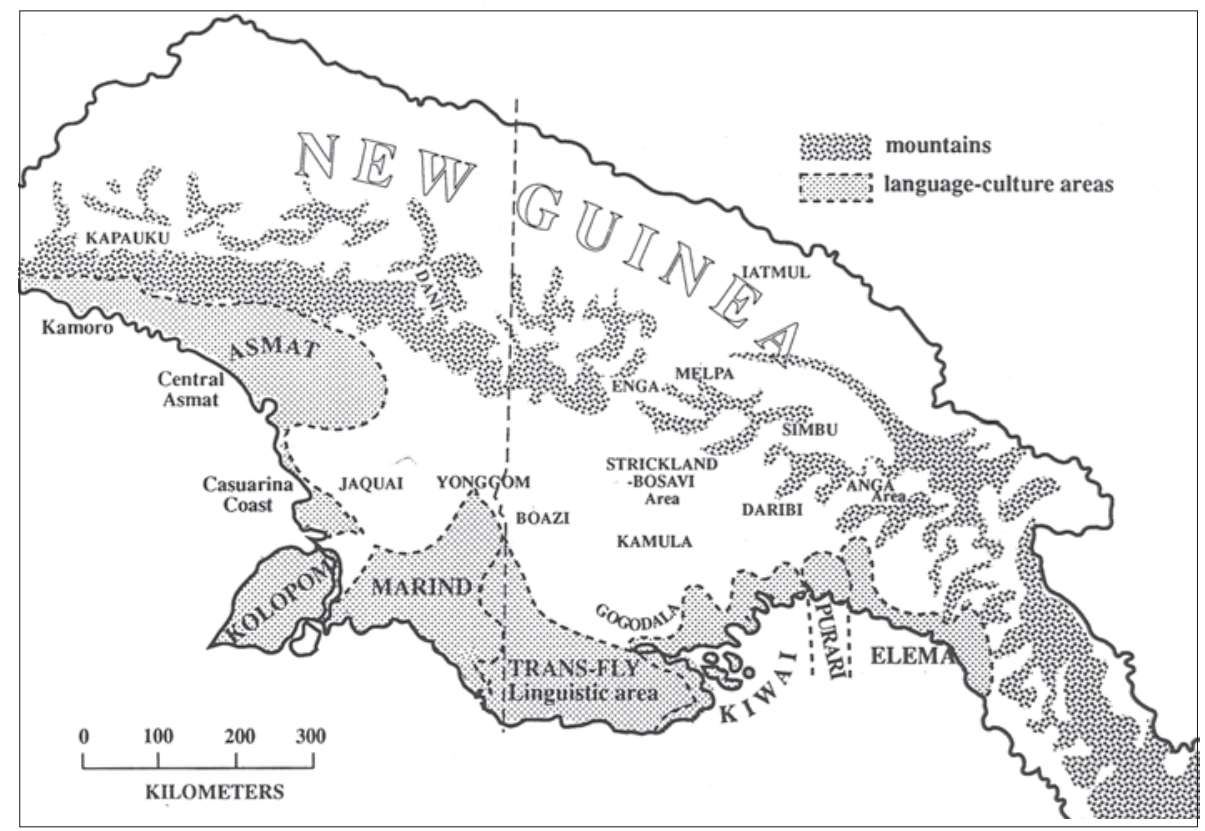

Map 4. Cultures (based on language used) on the south coast of New Guinea. From Knauft 1993:xiv.

These are summarized by Knauft (1993:37-41, 218-21) as follows. Additions, deletions, elucidations or cross-references that I make to quotations or texts referred to in Part Two or elsewhere in the book are placed between square brackets.

1. A variety of Papuan, non-Austronesian languages;

2. Abundance of wild [or semi-cultivated] sago stands, complemented by maritime or riverine resources [and supplemented in varying degrees by horticulture];

3. [Types of kinship and descent];

4. Potential [realized in varying degrees] for large-scale political affiliations or residential aggregates, despite a low population density;

5. Pervasiveness, in varying degrees, of multiple forms of dual organization and bipartition [including striking modalities of partition by gender];

6. Firm mythic-cosmological belief in the need for the regeneration of fertility;

7. A close articulation of these beliefs with:

a. commemoration of the dead; 
b. highly elaborate ritual enactment employing costumed or artistic embodiments [especially carvings] of mythical or ancestral beings [and recent dead];

c. elaborate heterosexual and sometimes homosexual fertility and rejuvenation rites;

d. warfare, particularly in the form of headhunting, to both reflect and augment the spiritual and social power of the local group.

Knauft notes that headhunting and ritual-ceremonial heterosexuality or homosexuality were absent among the Elema. Ritual-ceremonial homosexuality is absent among the Kamoro as well; the Kamoro ritual-ceremonial heterosexuality lacks the virulent intensity reported for the Asmat and the Marind. Unlike the Marind, Kiwai and Kolopom, the Kamoro and Asmat did not collect and apply male and female coital fluids. Admittedly, severing heads from bodies does occur in a well-known Kamoro myth of Kamora River groups, eliciting laughter among its listeners. An eloping couple chased by their relatives curse them to sink into the mud save for their heads, which are then severed by the elopers. They promptly feel regret and stick the heads back onto the torsos with resin. ${ }^{2}$ However, this narrative is a far cry from the elaborate ritual practice of headhunting, ascribed in a Kamoro myth exclusively to the Asmat. ${ }^{3}$ In various reliable reports about Kamoro pre-colonial warfare, there is no evidence whatsoever of headhunting or cannibalism (Pouwer 1953a:42-6; Harple 2000:105-7).

It seems that the features of Knauft's ethnographic region fade out towards its eastern and western borders. In East Elema, socio-political organization and patterns of social exchange approximate highland New Guinea ones; they were originally an inland population (Knauft 1993:204, 215). In West Kamoro, the mythical emergence of social groups as a result of dividing up a slain monster shows striking similarities to southeastern Bird's Head highland and lowland stories; only the manifestations of the monster differ (Pouwer 1999:480-8). Does this similarity point to age-old migrations, or to diffusion from west to east over hundreds of miles? The Kamoro narratives do mention pockets of small, scattered communities in West Mimika prior to the great migration from east to west. One wonders if the participants' explicit association of the myth of the slain monster with Ema Kame is not a historical afterthought. This could account for the remarkable absence of dramatization of this myth in Ema Kame rituals; the myth is, however, told in songs. Myths change more easily than rituals and ceremonial songs.

2 For the full text, see Offenberg and Pouwer 2002:26.

3 For details, see Offenberg and Pouwer 2002:195-7. 
Meanwhile, in spite of the similarities, the differences between the seven culture areas are so rich and of such a magnitude that Knauft is reluctant to force them into a comparative straitjacket by listing them. Doing so would also easily overlook the developmental configurations that are crucial for understanding intra- and cross-cultural divergence (Knauft 1993:209). But then, how are we to avoid academic, empiricist 'butterfly collecting'? Knauft attempts to overcome this Malinowskian dilemma by taking recourse to early Marxist concepts of social formation, social being, and social consciousness. He uses the term 'socio-cultural formation', which not only unites 'society' and 'culture' but, I would say, also 'process' and 'steady state'. 'Formation', as opposed to 'format', stresses ongoing activity. The Concise Oxford dictionary (2008) defines 'formation' as 'the action of forming or the process of being formed; a thing that has been formed; a structure or arrangement; a formal arrangement of aircraft in flight or troops'; indeed, a most fruitful collection of meanings. Further, to account for the process and dynamics of (socio-cultural) formation, Knauft re-casts the crucial Marxist concepts of 'social being' and 'social consciousness' into, respectively, the existential 'hard world' dimension and the symbolic dimension, or cultural impetus, of a social formation. ${ }^{4}$

Now, the strategic advantage of using this trio of concepts is that it enables us to grasp the reality of (social) formation as a truly dialectical process. As Knauft (1993:15) puts it, 'a core dialectic is constituted by the recursive qualitative impact that symbolic and existential dimensions of social action exert on each other over time. Along with internal cultural dynamics, this dialectic drives the endogenous development of socio-cultural formations.' On the other hand, 'the challenges, dissonances and refractoriness of culture's own existential manifestation provide tensions that drive development in the symbolic formation itself'. Knauft (1993:208) continues: 'Because the local interface between culture and practice [including history] is both recursive and generative, it produces remarkable differences among culture areas that nonetheless retain striking similarities.'

This reconceptualization of the Marxist trio produces in my view a relational dialectic, which rejects any final determination by either 'hard world' infrastructure or symbolic superstructure (see also Knauft 1993:14). As the neo-Marxist Althusser puts it, 'the last instance never comes'. What matters is neither 'matter', nor 'Geist', but the dialectical interface between the two in a given dynamic socio-cultural configuration. Put in a semiotic perspective, what matters is the events conceived as articulations, as relata, because the human (and animal) brain and the mind, having no immediate, direct access to reality, always articulate it. For instance, the hard-world phenomenon of 
sago stands in traditional South Coast New Guinea societies is articulated both as a physical-economic resource and as a physical-spiritual source of life; sago stands are not resources by themselves. Sago as articulated in this manner presents the people with both restraints and a boundless scope for signification, symbolization and creativity. A physical, social and spiritual articulation of sago in a modern, industrial society would be, and in fact is, radically different.

Knauft's neo-Marxist 'core dialectic' may in actual analysis be usefully combined with Lévi-Strauss's core notion of structure, more especially with structural history, a term he coined in 1960 in his inaugural address (LéviStrauss 1960, 1977:16). I cover ground similar to Knauft's and Lévi-Strauss's in my 'Structural history; A New Guinea case study', a semiological analysis of a Kamoro myth (Pouwer 1975:80-102). Structure in a Lévi-Straussian sense is a construct, an arrangement of complements rather than an empirical-statistical correlation of elements (Pouwer 1975:81). Hence it is accessible to reasoning, namely the logics of articulation, of signification by the mind, which has no direct access to reality: it is an analytical windfall that enables us to apply the logics of reasoning to the muddle of data and the flow of events. To Lévi-Strauss an arrangement is structured if it meets two conditions: 1 . it is regulated by internal cohesion; and 2 . this cohesion is not readily accessible to observation in an isolated system, but reveals itself in the study of transformations through which similar properties are recognized in apparently different systems (Lévi-Strauss 1977:18). These systems may be part of given configurations of a culture, such as the sub-systems of kinship and marriage, of politics, economy, ritual and myth. But they may also be part of a succession in time from one configuration to another. I define structural history as the study of the history of the succession of varying configurations in their dialectical interaction with the stream of events as articulated and signified. In terms of signification, the distinction between the order of events and the order of structure is merely an analytic one (Pouwer 1974:253, 1975:80-102). In other words, history 'happens' on the borderline between chance events and non-chance, non-contingent structure (Pouwer 1975:81).

It is on this borderline that Knauft's 'core dialectic' may be fruitfully situated. It has proven to be of great analytic value:

As cultural orientations were actualized in socio-material life, they were confronted with the often unintended existential effects of their own legacy. Repercussions of this nature were highly important in the development of each language-culture area. They are exemplified in the compromised fertility of the Marind; the relative defenselessness of the Trans-Fly people to ethnic encroachment; the relentless self-killing of the Asmat; the oscillating repulsion and spread of the Kiwai; the complete atomization of the Kolopom; the autonomous separation of Purari villages; and the great duration and economic scale of the Elema's hevehe. These 
outcomes reflect the recursive effects of divergent symbolic orientations as they became actualized in specific demographic, material, and biological conditions. (Knauft 1993:207.)

I would add that these conditions as articulated act upon the divergent symbolic orientations as articulated. From this development of each languageculture area to the succession of the next configuration in time is but one step. In this connection one is reminded of a profound remark by Durkheim, published in 1900: 'Structure itself occurs in the process of development. [...] It is ceaselessly forming and breaking down; it is life which has reached a certain degree of consolidation; and to distinguish it from the life whence it derives or from the life it determines amounts to dissociating inseparable things. ${ }^{5}$

Since Knauft deals only in passing with the Kamoro, which he saw as merely a small part of the Asmat language-culture area, ${ }^{6}$ I will attempt, in the following sections, to illustrate Knauft's dialectic by comparing the Kamoro with the Asmat socio-cultural formation. For the Asmat I rely mainly on Zegwaard's typed or cyclostyled reports and scattered notes, now available in the Zegwaard Archives of the Catholic Documentation Centre (KDC) at the University of Nijmegen. ${ }^{7}$ In addition, I refer to Knauft's observations in his main text and in an Appendix (1993:228-37), drawing on Zegwaard, Eyde, Schneebaum, Trenkenschuh and Sowada. I will proceed as follows: from a scrutiny, blow by blow, of the broad similarities, as listed above, will emerge a number of significant differences between Kamoro and Asmat. Can we account for them in a dialectical fashion?

\section{Languages}

The Kamoro language is spoken in a number of dialects, which cover the coastal and more inland areas from Etna Bay in the west to Koperapoka and the Mukumuga River in the east. The closely related Sempan language has speakers in the upper reaches of the rivers east of the Mukumuga. The neighbouring and little-known Nafuaripi presumably speak a Sempan dialect. They live upstream in a wide arc from Otakwa River to the upper reaches of

5 Durkheim 1953:190, as quoted in Lévi-Strauss 1977:17-8. Durkheim 1960 is an English translation of Durkheim 1900.

$6 \quad$ See Knauft 1993: Map 1, facing p. xii. See also mMap 3 and Map 4 in this volume.

7 Specific page-by-page acknowledgment of Zegwaard's information would be cumbersome and is not always possible for his scattered typed notes. Therefore, I refer simply to the Zegwaard Archives as 'KDC, File number'; the number as a rule refers to one item but may also include various items filed under one cover. 
the rivers around Flamingo Bay. The Asmat language area, beginning at the Momac (Le Cocq d'Armandville) River, includes a considerable number of dialects. They can be subdivided into a central coastal group of slightly differing dialects, with around it on the periphery upstream a number of dialects differing sharply from it, and the dialect of the Casuarinen Coast. ${ }^{8}$

The three languages are related yet different. They are classified as the Asmat Language Family, since speakers of the Asmat language dominate numerically: 40,000 to 60,000, compared to Kamoro's 15,000 and Sempan's 1,500, the Nafuaripi not included (Kamoro baseline study 1998:15). Despite considerable variation in dialects, there are no bars to comprehension within each language. The very differentiation into dialects and into three languages is evidence of longstanding migrations, and socio-political and cultural developments over hundreds of years.

\section{Sago stands, riverine, marine and horticultural resources}

The Kamoro, Sempan and Asmat share a vast, flat, marshy coastal plain and adjacent hinterland, densely covered with mangrove trees, tidal forests and rain forests, intersected by numerous rivers, creeks, and connecting shallow waterways. Yet there is significant ecological variation, which affects the size of the settlements. Since the central mountain range descends towards the coast in the far northwest and gradually recedes from the coast towards the southeast by several hundred kilometres, there is a difference in landscape and carrying capacity between the area west and the area east of Kaokonao (Central Mimika). In the former there is a clear, though continually shifting, borderline between a shallow sea and the land, marked by beaches and sand spits, enlivened by casuarina trees, and utilized for living and some horticulture. The rivers, creeks and connecting waterways west of Uta are fewer in number and shorter. Consequently, sago groves are not so abundant, there is more semi-cultivated sago (Amota pareta), and communications are more dependent on seagoing canoes originating from areas west of Etna Bay, which have almost supplanted the river-going canoes west of Kaokonao. In the east the shallow sea blends almost imperceptibly into the mudbanks and slush (rather than solid soil) of the coastal plain and into the aerial roots of the mangroves. An unusual extent of ocean incursion, as far inland as 125 kilometres at high tide, has created vast salty and brackish swamps. In these swamps extensive sago stands occur, at high tide extending to the middle and upper reaches of streams. Where the incursions of the tides cease, a different 


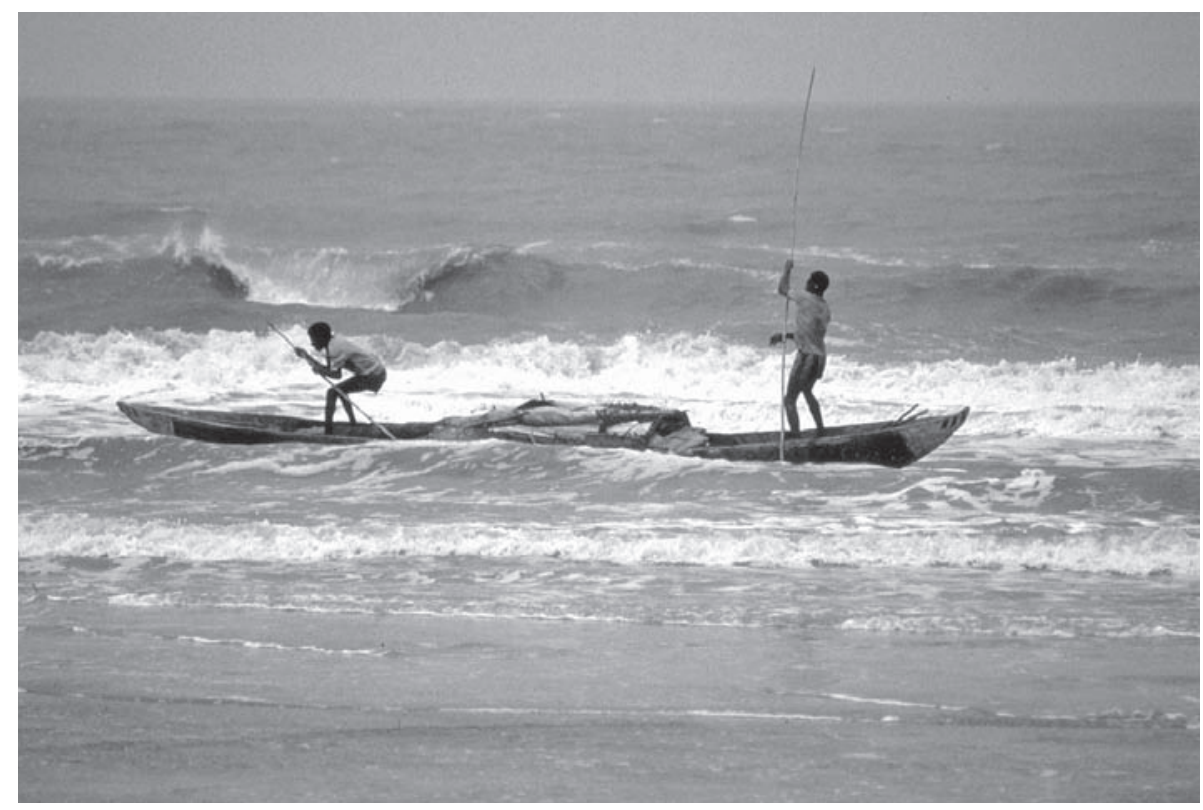

When the Arafura Sea is stormy, the only hope for a heavily loaded canoe is to pole it tediously along the boat channel inside the breakers near the shore. Near the portage to the Matoapoka River, Mimika, 1997. From Pickell 2002:164-5. Photograph by Kal Muller.

flora begins to dominate the riverbanks. Here there is an opportunity for gardening, especially on the upper reaches of the Wania and Mukumuga Rivers. This ecological situation is amenable to a higher carrying capacity. Whereas in West Mimika the size of settlements rarely exceeds 200 persons, in Central and East Mimika 200 or more is the rule rather than the exception. In coastal Central Asmat the upper limit is even 2,000. Inland settlements tend to be smaller (100 to 300 people) throughout the coastal plain. Another universal feature is a high degree of mobility, thanks to highly efficient dugout canoes well adapted to rivers, shallow creeks and waterways.

The ecological differentiation outlined above may be taken to constitute the existential dimension of the socio-cultural formations concerned. It is its dialectical interaction with the socio-symbolic dimension, as articulated, of the formations which determines their distinguishing features. 


\section{Types of kinship and descent}

Kinship and descent in Mimika and Asmat are roughly similar in that they combine a flexible, 'horizontal', strongly classificatory generation-type ('Hawaiian') of categorization of kin with a marked 'residential override', a term coined by Peter van Arsdale. ${ }^{9}$ Such a combination renders participants' thorough knowledge and recognition of actual and putative genealogical relationships, of descent lines and founding ancestors, superfluous and rather dysfunctional. Being a member of a domiciled core of kin is sufficient proof of being a relative. The paired terms of reference cemen/cen (Asmat) and kamare/wa (Kamoro), meaning penis/vagina and penis/anus respectively, are used, if need be, to designate the patrifiliation or matrifiliation of a particular person. A Kamoro man identifies his anus with his sister's vagina; he has two types of offspring: on the front side and on the back side, namely his own and his (classificatory) brothers' children versus his own and his (classificatory) sisters' children, his kamarima and his fatako. An Asmat man may even refer to his sisters' children by slapping his behind. ${ }^{10}$

Both the Kamoro and the Asmat strongly emphasize bonds between siblings as the core of kinship. The Kamoro refer to these in a generalized and metaphorical sense, irrespective of gender, by the term naoka-bikipa, literally 'younger/older brothers' (Pouwer 1955a:74). According to David Eyde the 'brothers', ofew, are the most important people for an adult Asmat male. This group includes not only younger and older (blood) brothers but also male parallel cousins and cross-cousins. It makes up the base of what Eyde has called a core conical kindred (Eyde 1967:210-303). These core kinsmen live next door to each other in a longhouse. In a metaphorical sense, ofew stands for kin in general.

The dualistic layout of Asmat and Kamoro local aggregates in a settlement, and the dual organization of performed ceremonies and rituals, enable persons of various kin and non-kin categories, including persons or groups originating from elsewhere, to assimilate easily without genealogical knowledge or connections.

Last but not least, the particular combination of generation-type kin classification, spatially expressed dualism, and residential override, allows for a flexible system of cumulative filiation or descent, attuned to locality of marriage, with some room for flexibility. There is a difference, though. The Kamoro and Sempan favour cumulative matrifiliation and matrilineal descent, the Asmat favour patrifiliation and patrilineal descent, corresponding to their

9 For details, see Pouwer 1955a:55-85; Van Arsdale 1975:12, mainly based on Eyde 1967:210303; Van Arsdale and Van Arsdale 1991:20. For the theory, see Pouwer 1966.

10 Zegwaard, personal communication, 1952. See also Pouwer 1955a:75. 
predilection for respectively matri-uxorilocal and patri-virilocal marriage. The Kamoro combine cumulative matrifiliation with 'horizontal', generational emphasis, by referring to male and female persons of ego's generation who have a mother's mother in common as 'my peraeko'. These peraeko often work together in sago production and fishing parties. Usually they live in the same settlement or the same part of a settlement. As a group and in a wider sense, they are referred to by the name of the focal grandmother. The group includes three generations and is exogamous. In the fourth descending generation the focal term of reference shifts to the name of another woman. ${ }^{11}$ The matrilineal peraeko of the Kamoro may be considered the counterpart of Asmat afayis cokom, literally 'grandfather one', those who have a father's father in common (Zegwaard and Boelaars 1955:286); this group is exogamous and patrilateral. The Kamoro and the Asmat share a low importance of lineal descent reckoning and an absence of named lineages exceeding three generations.

The reason for the (statistical) difference between matri-oriented Kamoro and patri-oriented Asmat could, and in my opinion should, be sought in a different style of political affiliation (see below). Adding to this difference is the fact that the Kamoro recognize and practise a clear distinction between superior bride-givers and inferior bride-receivers, combined with a preference for matrilocal marriage. In my description of Kamoro rituals, the special position of bride-receivers stands out. They are obliged to render a wide variety of services for their bride-givers, for which they are explicitly rewarded. Matriuxorilocal residence comes in very handy in such a situation. The special position of Asmat bride-receivers seems to be overruled by the strong and structurally fundamental emphasis on brothers. Though less conspicuous, among the Asmat the bride-receivers still occupy a rather special position. For instance, Asmat bride-receivers are required to assist in weaving masks for the benefit of their bride-givers. It is their duty to unveil a carved bow commissioned by their bride-givers to honour and avenge the death of a relative. Last but not least, bride-receivers are called upon to assist their bride-givers in acts of revenge during battles (Zegwaard 1959:1031).

\section{Residential aggregates and political affiliations}

Kamoro, Sempan and Asmat settlements consist of a varying number of localized descent groups in various combinations. ${ }^{12}$ The residential override of these aggregates is apparent from the literal meanings of their generic

11 For a striking persistence, compare Pouwer 1955a:76-80 and Harple 2000:234-6.

12 For more detailed descriptions, see Pouwer 1955a:85-107; Zegwaard and Boelaars 1955:24499, 1970:13-31; Van Arsdale 1975:10-2. 
names: taparu (Kamoro), yahe se (Sempan), yew se (Asmat). Taparu derives from tapare, meaning 'ground, territory'; 'taparu tapare enokoa' means 'taparu and tapare are one'. The linguistically closely related Sempan and Asmat terms literally mean 'longhouse mud'. 'Mud' refers to the mud-slab fireplace that prevents the fire from eating into the floor of the men's house. Each of the many doors in the longhouse corresponds to a fireplace (Zegwaard and Boelaars 1970:17). Yew se and yahe se stand for the men's longhouse, for the men's group, and by extension for the family dwellings around it and the associated kin group. The Kamoro have no separate men's longhouse, although there is some evidence for the pre-colonial existence of a special house (ate) for unmarried males (Van der Schoot 1969:36). In pre-colonial times they did have semi-permanent longhouses, situated upstream from the settlement and divided into (extended) family apartments, each with its own fireplace. In addition, there were and are temporary sites of simple, easily movable, matted family shelters near sago and fishing grounds.

Quite frequently, names of taparu are identical with or derive from the names of the territories they live on or once lived on; some of these names refer to features of the landscape. Other names refer to human beings, animals, birds, plants or natural phenomena featuring in narratives. These, however, are not considered ancestors, but may be associated with particular taparu or sets of taparu in terms of mythical power or ritual functions ascribed to members of the taparu. There is no evidence of totemism.

In a survey and a census including all Kamoro and Sempan settlements, I noted 160 taparu encompassing 8,500 people, which implies that the average size of a taparu is small (Pouwer 1955a:88). Although some names were identical or similar, a genealogical connection between two similarly named taparu was usually unknown or denied. Segmentation is conspicuously absent, in spite of frequent dispersion of persons and groups. Fragmentation is the rule. Residential override is so strong that interlocal genealogical ties easily lapse. One consequence of this is that, with the exception of cases of regular interlocal intermarriage, men or women originating from one village who settle in another village, for marriage or other reasons, may consider each other peraeko or close kin, irrespective of known or unknown genealogical or taparu connections, solely on the grounds that they have their settlement of origin in common. ${ }^{13}$

In keeping with the trend of increasing size of settlements going from northwest to southeast, the size of taparu east of Kaokonao and of the Sempan yahe se tends to be larger. Everywhere, taparu of limited size tend to be exogamous. They have a core of peraeko sets, which consider themselves closely related, 
even though genealogical interconnections are hardly known. In larger taparu, such as in the Wania region and in Sempan villages, the number of constituent peraeko sets is bigger and their genealogical relationships further removed. These units tend to be non-exogamous. Everywhere, marriage within the settlement, or within the river-bound association of settlements, is preferred.

The Asmat conforms with these trends in its own special way. A yew has at least 150 members, usually more (Zegwaard 1955:241). A men's house may be as long as 50 to 90 metres and may have ten or more doors and corresponding fireplaces, owned by 'brothers'. Their related families live around it in ten or more compartments of longhouses. Though the typical community includes several men's houses, each yew is a potential village (Eyde 1967:109). In a similar vein, some of my Kamoro informants in East Mimika labelled taparu as kampung (Indonesian: village). Van Amelsvoort (1964:39) reports that an Asmat man strongly identifies with his yew, but feels little loyalty to the community or village. Though less conspicuous, among the Asmat the bridereceivers still occupy a rather special position. A yew differs from a taparu in that it consists of named moieties, aypim (literally 'halves'). Each moiety has and builds its own half of the men's house and its adjoining row of (lower) family longhouses. One moiety relates to the other as the root of a sago palm to its shoots (Eyde 1967:98-100; Voorhoeve 1965:31). Their relative position is one of superior downstream to inferior upstream, even if the factual geographical position is the reverse of this because of fission of moieties or yew. Marriage is ideally aypim-exogamous and yew-endogamous. An actual analysis of Shuru by Zegwaard and Boelaars in 1953 (Zegwaard and Boelaars 1955, 1970) shows that more than half of the marriages are within the yew. Exchange of women may be and often is delayed in time and generation within a yew, but is usually not delayed outside a yew.

Coastal, downstream and midstream Asmat settlements, with 400 to 1,400 inhabitants, have three to five yew, whereas settlements situated further inland, often considerably smaller in size, have even more yew, sometimes up to fourteen (Van Amelsvoort 1964:39, 190-1). In West Mimika we also noticed that smaller settlements tend to have relatively more taparu. ${ }^{14}$ In my opinion the reason for this remarkable paradox is that smaller settlements and smaller yew/taparu go together with a larger dispersion of smaller wild sago stands and more numerous semi-cultivated sago groves. A larger concentration of largely wild sago stands favours larger settlements, and a smaller number but bigger size of yew/taparu. In a valuable comparative analysis of Kamoro and Asmat settlement patterns and demographic data based on missionaries' and government information and his own and my research, Eyde concludes 
that '[t]he maximum stable units of Kawenak and Keenakap life [surroundings and western hinterland of Central Asmat Flamingo Bay, respectively] are twice as large as those of the Keenok [northwest inland Asmat], and twice as large as those of the Kamoro' (Eyde 1967:148). He continues:

It is everywhere [in Asmat] the case that the largest villages on a river are located in its middle course. The villages towards the coast are somewhat smaller; those inland are usually very much smaller. This middle zone represents, in general, the optimum balance between tidal swamp and fresh water swamp. It can, therefore, support a relatively larger population than areas downstream or upstream. (Eyde 1976:155.)

In my view this observation also applies to East Mimika and to Sempan.

This ecological interaction has important implications: the more manpower per yew and (association of) taparu, the stronger their political/military potential. Whether and to what extent and for what purpose this potential is realized is another matter.

It is in these areas where the rivers are wide and long that

competition for sago and fishing areas between unrelated groups residing up and downstream from one another has resulted in the development of a state of intensive warfare, which is not duplicated in the western Kamoro and Casuarine Coast, where the rivers are short and groups possess territories comprising both tidal swamp [fish] and fresh water swamp [sago]. Increased solidarity of males resulting from cooperation in intensive warfare has led to the development of men's houses or bachelors' houses [Yeenok]. [...] These are absent among the Kamoro and on the southern Casuarine Coast. (Eyde 1967:304.)

Wars were not absent in Mimika, but lacked the intensity and virulence of Asmat warfare. Unlike Asmat wars, Mimika wars were not a regular feature or obsession of daily life.

This takes us to the territorial and political affiliations between self-contained local aggregates. Although Kamoro taparu are not divided internally into moieties, they do tend to operate in dualistic, river-bound groups, which in my PhD thesis (1955a) I named 'tribes'. The taparu of an association used to live together in a semi-permanent settlement (later reconstituted and sometimes reshuffled in government-styled villages). Such a settlement is either divided into wards per taparu or into named parishes, each comprising a varying number of taparu. In the course of my fieldwork I counted 50 associations, each constituting a security circle. Three of them no longer exist; 21 consist of two taparu; the remainder are parishes, which, like the Asmat yew halves, relate as downstream to upstream. Some of these parishes are even subdivided into spatially marked sub-halves. These associations are usually not named. 
In their turn many adjacent settlements are federated in pairs. Some federations include more than two settlements. There are 15 paired settlements, and four associations that include more than two settlements. The latter, plus two paired ones, each have a name of their own. These six affiliations, with considerable numerical strength and guided by one or more powerful 'big men' (we ayku), pulled their weight in warfare. ${ }^{15}$

The Asmat federations are similar to the Kamoro ones, but there is a difference in scale due to the larger size of the components. A systematic survey of affiliated settlements is sadly lacking but some are at least known by name, such as - going from northwest to southeast - Emo-Espeno, Ac-Nakay, Yamas-Yeni, Yaun-Yufri, Saowa-Erma, Per-Owus, Aman-Namkai. Fortunately Zegwaard provides a unique, fairly detailed description of the oral history of affiliations of the Bismam group at Flamingo Bay, in particular those of Shuru, where he lived in $1953 .{ }^{16}$ For locations, see maps 2 and 3.

When the grandfathers of the present (in 1953) grandfathers were young, the inhabitants of the paired yew Ewer-Shuru lived downstream and the Uwus-Per upstream in one settlement on the upper reaches of the Bow River, above present-day Owus. The culture hero Beworipic and his wife Tewerawoc are said to have founded this settlement (Van Arsdale 1975). Headhunting and its associated ritual are ascribed to him and his brother Desopic. ${ }^{17}$ The Bayit, now forming a yew within Shuru, then lived elsewhere on the Bow River. At that time the paired settlements of the Yepem and Kaye yew were located respectively near and on the upper reaches of the Mani River (upstream of the present Per, Van Arsdale 1975). The Yepem now lived at the mouth of the Yomat; they had migrated there from the Citak region.

Then the upper Bow group began to split up. A man from Shuru killed a man from Amborep. This triggered a brawl about the dead body, a trophy for ritual headhunting festivities. The Owus snatched the body but the Shuru took it back. A Shuru man was wounded and, by way of retaliation, an Owus man was beaten up. The Owus then spread the rumour - a common political strategy - that this man had died. After a fight the frightened Shuru-Ewer took to their heels and fled to the mouth of the Bow River, later to the Ba River near Shuru's present location.

Owus realigned with the yew of Seper at about the present location of Owus, whereas Per moved to the upper Mani and associated with Kaye. Some time later, warfare broke out between the former allies: Owus-Seper against

15 For more detailed information about associations, see Pouwer 1955a:90-1. Lists, detailed by village, can be found in Appendix III, V and VI of Pouwer 1955a:282-7.

16 For additional information, see Zegwaard and Boelaars 1955:248-53; Zegwaard and Boelaars 1970:15-7; Van Arsdale 1975:56-60.

17 On the initiating myth and ritual, see Offenberg and Pouwer 2002:192-5. 
Per-Kaye. Kaye's warleader died, causing dissolution of Kaye and the mixing of its people with other Bismam settlements, particularly Shuru-Ewer. A present-day remainder of Kaye's influence in Shuru is the moiety of Bayen of the Shuru yew Awor (Van Arsdale 1975).

Then Ewer-Shuru split apart after a Shuru man raped an Ewer woman. In the ensuing retaliation by Ewer, the woman's father was wounded and died. Eco pok, signs of revenge, were erected. The two parties, anticipating killing and counter-killing, then agreed to pull out. They moved to their present locations. In 1904, when the ship 'Flamingo' sailed along the coast of Central Asmat, the Shuru stayed on their own at the present location of the Faramap River, whereas the Ewer lived at the mouth of the adjacent Ba River (Van Kessel 1962). Ewer associated with two other yew, which at a later stage dissolved and were incorporated into yet another yew, a new one (Van Arsdale 1975).

At the time of the Ewer-Shuru split, the settlement of Shuru consisted of the Ndendew yew (Nano yew in Zegwaard and Boelaars 1970:15) with its moieties Ndendew and Onom. In the course of time a number of fissions occurred, which I present in a diagram (Figure 4) for the sake of clarity: (a) a newly founded yew, Setmut, splitting up into Setmut-Ar; (b) Awor splitting up into Awor-Bayen; (b1) and (b2) temporary dual splits of Awor and Bayen respectively, which did not last; (c1) and (c2) temporary dual splits of first Onom and then Ndendew, which did not last either, for lack of numerical strength; then Ndendew and Onom reunited; (d) Ar splitting up into Ar-Baser; (e) Setmut splitting up into Setmut-Yismak. All these fissions resulted from conflicts of one kind or another.

So in 1953 the settlement of Shuru consisted of the mother yew Ndendew (-Onom) and five daughter yew deriving directly or indirectly from her. The moieties placed left in the compartments of the diagram give their name to the yew concerned. They relate to their partner moieties as downstream-superior to upstream-inferior. Ndendew-Onom and its Awor-Bayen branch (b) lived together downstream and related as superior to upstream Sotomot-Ar in their original settlement on the river.

Bayit-Wauco originated from the Momac River and joined Shuru after a number of moves. Along with a few people of the Awor moiety (Bayen), BayitWauco are the only ones not deriving from Ndendew.

We may conclude from the data that residential override and modalities of spatially expressed dual division - also operating clearly in ritual - dominate and permeate not only the social pattern but also the dynamics of the three societies concerned. Their constituents, kinship, (cumulative) filiation descent, if you like - genealogical knowledge and genealogical relations, and marriage patterns (though all of these are social phenomena and forces in their own right) are clearly conditioned by residential override and dual division. The latter provide an anchor for the instability brought about by endemic con- 


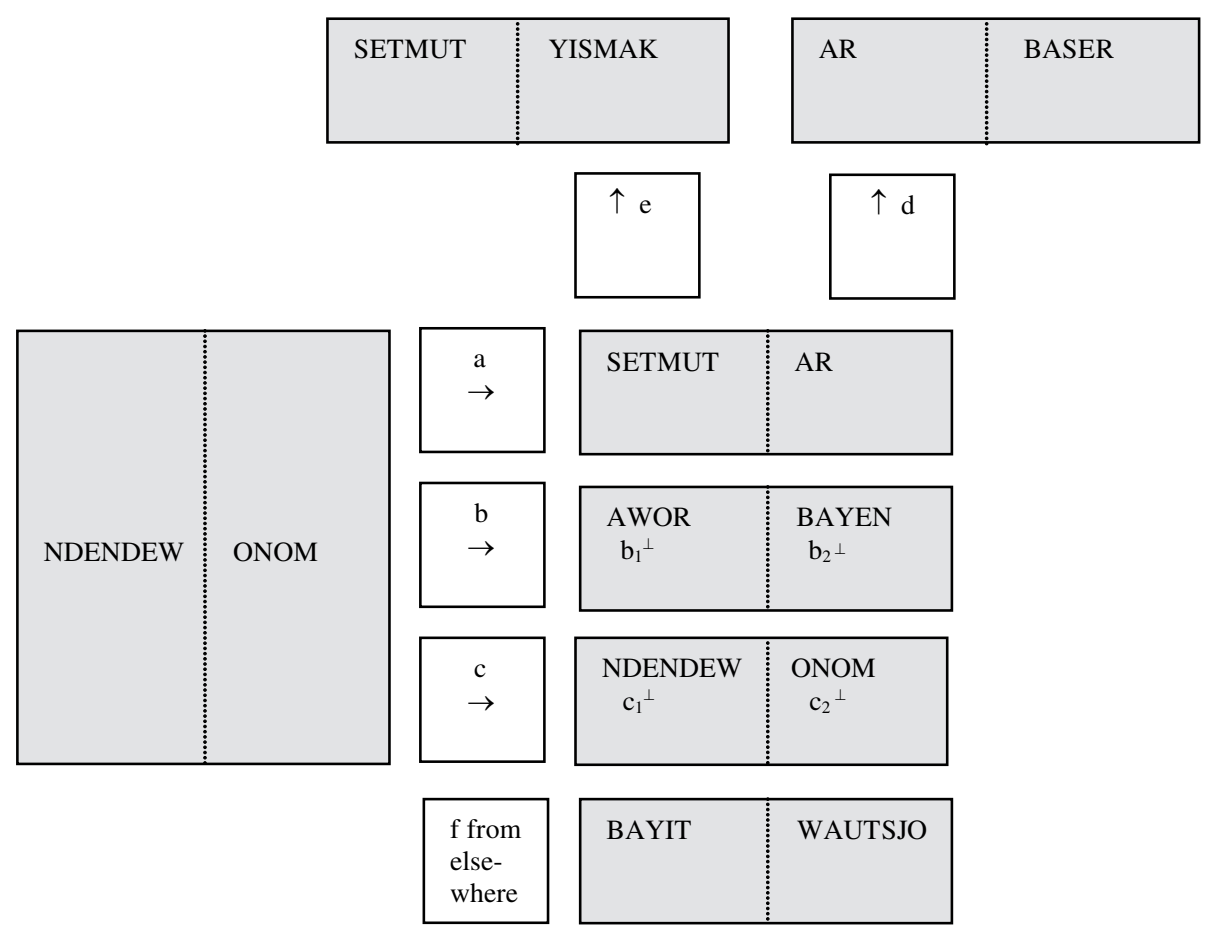

Map 4. Fission and fusion of yew in the Asmat settlement of Shuru

flicts, warfare, and subsequent shifts in domicile and affiliation.

The carrying capacity - an ecological interaction of individuals and communities with their physical environment as defined, articulated and signified in a dialectical process - tends to condition the differential manpower and associated political power of the communities, gradually gaining strength from northwest (Etna Bay) to southeast (Casuarinen Coast), particularly in the coastal and downstream regions.

However, these two types of conditioning, socio-political and existential, do not determine the total configuration of the socio-cultural formations concerned. First of all, each type of conditioning is in itself an open, never-ending dialectical process between people being conditioned and at the same time acting as conditioners through their articulating and signifying social practice. More especially, their symbolizing capacity, the complement and counterpart of carrying capacity, provides the social formation with its central impetus. It is this impetus which turns the (semi-)autonomous components of a social formation into a totality: it literally con-figurates them in a never-ending, 
never-closed, dialectical process. Its very 'totalizing' nature provides this central institution with multiple faces. Therefore, if it is observed that a particular social institution has multiple functions, this may indicate that the institution operates as what Marcel Mauss called a 'total social fact', taken here to mean a totalizer that functions as a cultural focus.

In modern Western societies the multiple faces and functions of the economy mark it as a totalizer. It seems to me that the Asmat social formation differs from the Kamoro one in that endemic political rivalry and warfare spearheaded by headhunting - act as a totalizing force. The evidence for my suggestion is provided by Zegwaard (1959). He concludes from his description of headhunting that it should be evaluated in the light of a complicated set of factors, which he spells out (Zegwaard 1959:1041). In other words, headhunting has many faces; these will be discussed in a separate section in Chapter XI. Cannibalism is merely a secondary part of this (Zegwaard 1959:1020). Meanwhile, it should be noted that the virulent, violent nature of rivalry and warfare and headhunting can easily turn this totalizer into its very opposite: a fragmentizer, even a self-killer. The dog bites her own tail in deadly dialectics. The Shuru case, and other Asmat ethnographic and historical evidence, supplies us with ample examples. Knauft concludes from a worldwide ethnographic tabulation that the Asmat killing rate is among the highest in the world (Knauft 1993:194). Numerous settlements have been wiped out or dispersed, or have seen their remnants absorbed into other communities. Zegwaard knows of 20 yew, or communities of yew, which have been wiped out or dispersed. The settlement of Kaimes, which had about 400 inhabitants at the time of the Military Exploration (1910-1913), no longer existed in the 1940s. Only 20 persons who trace their descent to it survive, having been assimilated by Ewer. From personal experience during his first stay in Shuru (1945-1947), Zegwaard reports 61 confirmed casualties, 56 of them having been eaten by Shuru's enemies: 16 men, 18 women, 22 children out of a total population of 675 . At that time Shuru was a favourite target because it had lost physical strength as a result of the Japanese killing of 21 married men and one bachelor. During his second stay, in 1953, Zegwaard had personal knowledge of 83 casualties in one year, due to headhunting between settlements in a 50-kilometre semi-circle around Flamingo Bay. He estimated that about 2 per cent of the population per year was killed by war and headhunting (Zegwaard 1977:22-5).

A striking example of the relation between differential carrying capacity on the one hand, and differential symbolizing capacity on the other, is provided by the difference (alongside the similarity) in impact of the consumption of sago shoots or sago hearts (known in Western countries as palmite or millionaire's cabbage), and of sago grubs. Throughout the region these forest products are highly valued as delicacies. Since they are an important source of protein, 
they add considerably to the carrying capacity of the physical environment. Sago grubs are even 'cultivated', by felling sago trees, cutting the trunk into chunks, and opening these up to the pith inside, in order to better enable the capricorn beetles to lay their eggs. Maturing takes four to six weeks.

There is more to these delicacies: they function throughout the region as a social good (biens sociaux). In the entire Kamoro-Asmat region a lover may express his - or more particularly her - feelings towards the object of affection by secretly offering a serving of fresh or fried sago grubs. Furthermore, almost any distribution of food during ceremonies and rituals, including the remuneration of services offered (especially the services of bride-receivers), involves giving or exchanging sago shoots and sago grubs. The Asmat, however, unlike the Kamoro and Sempan, tend towards a seemingly excessive consumption of the two. Zegwaard reports that hundreds of sago palms, presumably the more highly valued young ones, were felled in Shuru in 1953 for the acquisition of sago shoots and the cultivation of sago grubs, on the occasion of the ceremonial inauguration of a new men's house. At that time Shuru had about 650 inhabitants. ${ }^{18}$ Father Alphonse Sowada, attending a similar ceremony in Ac, with a population of over 1,300 in late 1969, counted somewhere between 700 and 900 sago shoots. ${ }^{19}$ In the course of another, related ceremony, Tow Mbu, a huge funnel-shaped tube about three metres long with a diameter of at least one metre at its top, is filled with hundreds of sago grubs. During the Kaware celebration of the Kamoro, both similar to and different from Tow Mbu, sago grubs also feature in a ceremony, but not in this way, nor in such huge quantities. In the 1950s Sempan villagers in East Mimika complained about Asmat invaders ruining their sago groves while searching for sago shoots. According to the oral history of the Bismam group of Asmat, and the Kamoro narrative of the great migration as discussed earlier, a scarcity of sago stands and famine are important reasons for temporary or permanent migrations, hostilities and wars. ${ }^{20}$ In the light of the excessive consumption of these social goods, one wonders whether this scarcity is due not only to poor quality sago (Van Arsdale 1975), but also to human causes, namely excessive felling and overexploitation for the sake of sago shoots and sago grubs.

Why this excessive Asmat consumption of social goods? The answer may be found in their connection with rivalry and warfare as a totalizer of the Asmat socio-cultural formation. In addition to having an emotional and social function, these delicacies also have a crucial symbolic meaning. Zegwaard describes the symbolic meaning for the Asmat - and probably also for the Kamoro - of sago grubs in particular, as spiritual power-food: it provides the

20 For Bismam, see Van Arsdale 1975:55. 
many minor spirits (Asmat: nam yipi, Kamoro: ipu), located in particular in the joints which keep the body moving, with strength and vigour. Sago shoots and sago grubs are consumed in large quantities by Asmat prior to and after an attack. A related function of the sago grub for the Asmat is that its smell, together with the strong odour of a smoking stick rubbed with the fat of a cassowary, is believed to attract the souls (nam yipi) of the leaders of a hostile village. Their bodies will follow their souls, so that they will be an easy prey for the men with the 'smoking guns'. ${ }^{21}$

Every Asmat moiety and yew has a key figure. The extent of his influence is based, in addition to kinship, on his personality and his abilities (or lack thereof) as political spokesman, as primus inter pares. His political power and the protection he offers may affect the residential pattern in that followers, irrespective of kinship status, may wish to settle near him. Outstanding 'big men' (tesmaypic) almost literally embody the totalizing impetus of rivalry and warfare. The famous 'big man', warleader, and successful headhunter Warsekomen of Shuru, a key informant for Zegwaard in 1953 and still an important man in 1970 in spite of his age, is a prime example. ${ }^{22}$ His power was determined by the following factors: 1 . leadership of his yew Ar and the closely associated yew Setmot, which together constituted almost half (45\%) of Shuru's inhabitants; 2. his marriage to seven wives from other yew; 3 . his being a partner in a ritual wife swapping (papish, see Chapter XI) by six men; 4 . his relations with brothers and sisters and their offspring; 5 . his ties with relatives in four other settlements; 6. the shamanistic abilities (namer ow) of his wives (see below); 7. his abilities as an organizer and leader of ritual; 8 . his strong personality and intelligence; and 9. his thorough knowledge of narratives and history. All these factors enabled him to mobilize a maximum of material resources and manpower for warfare and headhunting. His many marriages gave him extra access to sago groves and fishing grounds. He acquired and boasted of a considerable number of captured heads in battles with various settlements.

Admittedly, Kamoro and Sempan also had their warleaders of repute. Like Asmat history, Kamoro and Sempan oral history after the great trek is marked by skirmishes and battles between settlements (or federations of settlements) and subsequent resettling. Yet there is a difference in frequency, scale, ferocity, and number of casualties. Most importantly, headhunting was not part of Kamoro and Sempan history. Similar to Asmat, Kamoro rivalries could also erupt within a settlement; likewise, casualties within a settlement were low and were preferably avoided. In Tipuka (Wania River, East Mimika) I recorded a vivid story, apparently also meant as entertainment, describing

21 See Zegwaard's 1988b comments on Schneebaum in Konrad, Konrad and Schneebaum 1981:109, 179; for more details, see description of Firao Wu and Tow Mbu ritual.

22 See a comment by Trenkenschuh in Zegwaard and Boelaars 1970:18. 


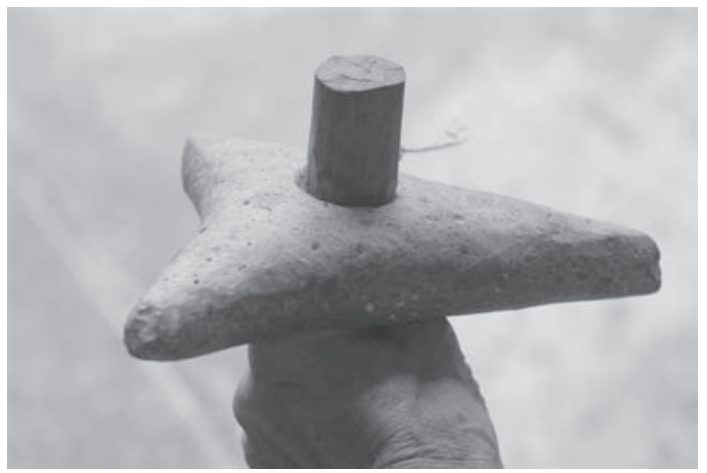

Star-shaped stone head of a club collected by Kal Muller in Ipiri, November 2006. Photograph by Kal Muller.

how an indecent love affair by a young couple, engaged in public bantering and mutual scratching, deteriorated into a full-scale, full-day brawl into which everybody was gradually drawn (Pouwer 1953a, Appendix XXV). The combatants were initially hitting out with any piece of wood at hand, but soon replaced these with professional clubs (mapipu) consisting of a shaft inserted into the round hole of a heavy, star-shaped stone. Everybody sustained cuts and bruises, though there were no casualties. Nobody could walk properly any more, but still the clubbing went on, even while sitting and lying down. Nevertheless, the story has it that at the end, the lover boy was carried around the settlement on the shoulders of the fighters, and the sticks and clubs were thrown onto a heap, signalling the end of the brawl. People of a nearby settlement treated the wounds with leaves and provided the exhausted combatants with pork and sago grubs.

The very same Tipuka, however, was attacked and decimated in a full-scale battle in about 1900, which is well remembered throughout Mimika. At that time, together with downstream Atuka, it was the most powerful community of the Wania region. Its people were at odds with its host neighbours on the Wania River and with nearby communities on the Koperapoka River east of them. Initially they had lived there - after migrating from an area east of the Mimika region - but they pulled out after they had killed a man of the Buka parish during a joint celebration of Kaware. They overpowered their host neighbours during numerous conflicts, involving among other things the exploitation of sago groves they were not entitled to. So there was plenty of willingness in surrounding communities, even communities on the Kamora River, to teach the Tipukans a lesson and break their power. When the Tipuka 


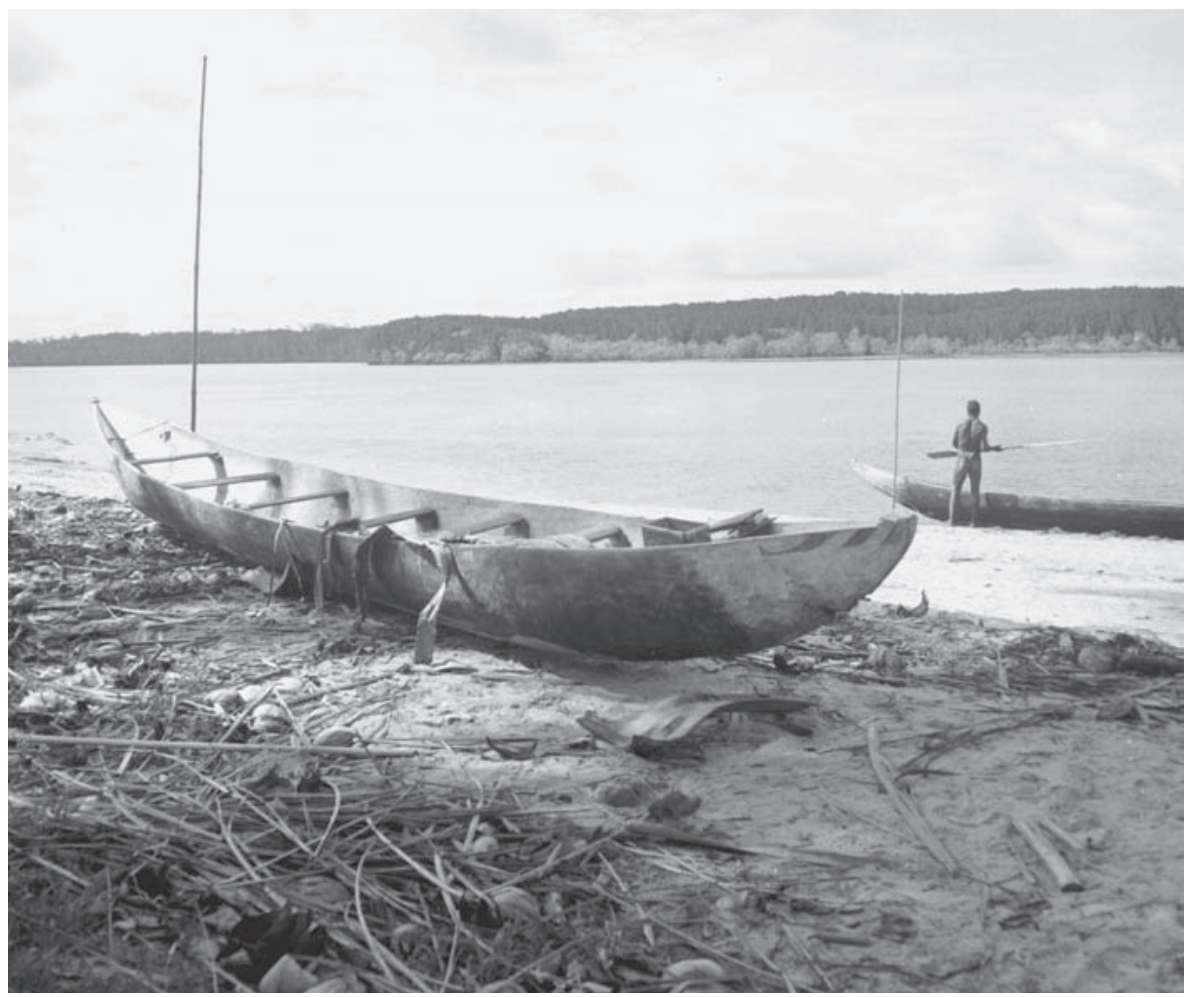

New seagoing canoe fabricated by Poraoko people (far western Mimika) in exchange for permission to gather sago. Ipiri sago groves, February 1954. RMV: NG-54-61.

Photograph by Jan Pouwer.

men, in the final stages of their celebration of Kaware, left their settlement at the beach to go on a pig hunt, a war party of allied neighbours took this opportunity to attack the village. This war party killed the older women and imprisoned the younger ones and children. Tipuka men were also killed or caught; they fled in all directions. The aftermath of the battle saw Tipukans scatter throughout the area; many are known to have been traded as far as Arguni Bay west of Mimika. Descendants of the imprisoned men and women can still be found in the Koperapoka, Wania and Kamora settlements. In my 1952 census of Tipuka only 130 inhabitants were registered. ${ }^{23}$

Significantly, my informants throughout Mimika attributed the joint, massive action against Tipuka not to political threats or violations of claims to 
sago groves but to anger at Tipuka men for having been careless in keeping Kaware secrets hidden. Because of the men's carelessness, these secrets came to the attention of female guests attending the Kaware ceremony. Even if this argument was used merely as a pretext, it does point to the supreme value attached to safeguarding sacred ritual. It is firmly believed by men and women alike that violation of ritual taboos endangers the society (and the status of males). In my discussion of Ema Kame I mentioned that fears for people's health were expressed because of the inclusion of a ceremonial play in a programme celebrating the Queen's Anniversary. And when the wives of my houseboys accidentally noticed the pointed bottom of a used spirit pole stored behind my house in Kaokonao, before I dispatched it to the National Museum of Ethnology at Leiden, their husbands were terrified and concerned about their wives' health. A specialist ritually cleansed these women by means of a spell. Finally, my informants in Ipiri and Yaraya criticized the performers of the spirit platform ritual in Kaokonao in 1954 (see Chapter V), for not sufficiently safeguarding secrets from women's curiosity.

For me as an observer, the reason stated for the massive attack on Tipuka around 1900 and the fears described to me in 1954 are just a few of many indications of the viability of the ritual cycle's function as the focus and as a totalizer of Kamoro society and culture.

Returning now to the carrying capacity of the physical environment, this forms a condition for a given group's manpower and political power. Going from northwest to southeast, the groups gain in strength. Even so, precisely in the far western part of Mimika where, due to a receding hinterland, wild and semi-cultivated sago stands are scarce, a politically powerful federation of settlements operated under the collective name of Tarya We around 1900. It included the fairly small settlements of Poraoka, Kipia, Maparpe, Wumuka and also Umar and Ayndua. They operated together in acquiring access to the sago stands of settlements east of them, down to Ipiri and Yaraya, often in exchange for seagoing canoes and with a show of power. Their 'big man' and ruthless, legendary warleader, considered the terror of Mimika, was Naowa, well known and feared, from Etna Bay to as far as Central Mimika. This situation seems to contradict the correlation between abundance of sago stands and power. So where did Naowa's power come from?

The lack of natural resources and the scarcity of manpower were compensated for by the fact that the Tarya We occupied a key position in the Etna Bay area in the acquisition of Western commodities in high demand, such as iron tools, cloth, and body ornaments. Manpower was supplemented by firepower through the acquisition of guns. A beach near Yaraya, west of Kaokonao, was named Minaki Tiri ('gun beach', Pouwer 1955a:222) in commemoration of an attack by a war party of Noawa, which killed locals with shotguns. 
By 1800 there was an Islamizing trade-centred network linking the western part of Mimika with the Onin Peninsula on the southern side of the Bird's Head. There were even direct links between the West Mimika coast and the Moluccan islands, interpreted by narratives in a Kamoro-centric way. ${ }^{24}$ Naowa was appointed raja by the Islamic merchant-raja of Namatote, who had relations with Seramese traders and officials, and in his turn empowered his cronies at various settlements in West Mimika by granting them a plethora of Moluccan titles. Kipia became a central location for Kamoro's increasing appetite for ironware, tobacco and clothing. Tipuka, Atuka, and the Koperapoka settlements in the far eastern part of Mimika traded women and children as prisoners of war (manuku) to Naowa and to Etna Bay traders. Kaimana had a Kamoro colony in the 1950s, originating from Kamoro slaves imported there. Naowa and his allies attacked parties from Central and East Mimika, travelling to the far western part of Mimika to acquire Western commodities. He took quite a few Kamoro people captive, even stealing their captives and freshly acquired ironware. Communities between Uta and Kaokonao fled temporarily to the eastern Wania region, when Naowa treacherously attacked them after a ceremony of reconciliation (Pouwer 1955a:222-3). Islamic commercial expansion, via the emergent Tarya We's political affiliation, came to an end with the gradual establishment of colonial rule and the arrival of Chinese traders and the Roman Catholic Mission in its footsteps. Even so, in the 1950s I noticed some survivals of Moluccan-Islamic influence in West and Central Mimika. Village elders still claimed Moluccan titles such as raja, mayor and hakim. They had a predilection for wearing a topi by way of turban, and had at least the stated intention not to eat pork (Pouwer 1955a:255).

One may conclude from this comparative analysis of political affiliations that three cultural configurations - Central Asmat, Central and East Kamoro, and far-west Kamoro - have many traits in common, yet differ significantly in dominant orientation: they are similar yet different. It is obvious that natural resources and history (wars, migrations and trading) played their part in the emergence and differentiation of these orientations in a dialectics of the existential with the symbolic dimension of the social formation.

\section{Pervasiveness of dual organization}

Most of the multiple modalities of dual organization were discussed in the previous chapter. Bipartition also underlies the organization of Kamoro, Sempan and Asmat rituals, including the organization of the guild of drum- 
mers and singers. Rituals and drumming are used first in performances of the 'right' (Kamoro: mbaowooko) party or person, followed by performances of the counterpart (Kamoro: aopao), the 'left' (Kamoro: pakare) party. 'Right' usually relates to 'left' as root/bottom to branch/surface, on the analogy of a tree. 'Bottom' stands for origin or prior entitlement, 'surface' for derived or secondary entitlement. This also holds for Sempan and Asmat. The relationship between the two parties, though asymmetric and characterized by competition, is basically one of repetition and of complementarity. The Kamoro even conceive of the human body as a complementary duality; significantly, the right part is associated with the mother, the left part with the father.

Although the division by gender seems commonplace and universal, it must, just like sexuality, 'be analyzed as part of a whole, contextual, social tradition' ${ }^{25}$ This is strikingly apparent from the Kamoro division of rituals into 'female' and 'male' ones, as discussed in Chapters II and III. Gender functions as a pervasive ritual totalizer. Among the Asmat such a division is not as explicit, but is nevertheless present. The location of all rituals, except Emak Cem, the counterpart of Kamoro 'female' Ema Kame, is the men's house. Emak Cem is the only ritual with a ceremonial house $(\mathrm{cem})$ of its own. Its origin, as well as the origin of the wuramun or uramun, the spirit canoe, on top of which the Emak Cem initiation of male adolescents takes place, are attributed to the two crucial culture-hero brothers (or cousins) Kurap and Sarawap. They built the first-ever ceremonial house according to the instructions of their two mothers, who relate as sisters and are represented as snake women (ancestral mothers). In the upstream Kapi version these women even build the house themselves. Furthermore, two female dignitaries unveil the spirit canoe when the ritual is performed; they, not the men, also lift it up at the start of the initiation. ${ }^{26}$ Yet 'male' rituals dominate among the Asmat, whereas 'female' ones are preponderant among the Kamoro and Sempan. Asmat 'male' stands for virility, Kamoro 'female' for production, reproduction, and fertility.

Male and female status, though obviously a component of the broader socio-cultural division by gender, deserves a separate discussion. In this discussion I follow Knauft (1993:86-116), Herdt (1984:66), Feil (1987:170) and Sanday (1981), considering female status as reflected in: 1. women's sexual and marital choices; 2 . female acquisition of and control over culturally valued property; 3. female participation in public affairs and ritual celebrations; 4. incidence of female pollution and images of women; and 5. incidence of wifebeating and domestic violence.

Unmarried Kamoro women are very active in arranging secret meetings

26 For a more detailed description of the Asmat Emak Cem ritual, see Chapter VII. 
with men in the sago areas using verbal and body language, directly and often indirectly. To what extent these secret meetings lead to betrothal and marriage is, however, decided by the relatives of the romantic couple. The young man and young woman do have a say in the decision though. Nevertheless, since marriage is a social event requiring sister exchange, preferred as the ideally 'right' marriage to a 'left' marriage by brideprice, individual sexual or marital choice is overshadowed by considerations emanating from the relation between bride-giver and bride-taker. Romantic choice and marital choice may sometimes correspond, but often clash. There are three socially condoned traditional ways out. First, marriage by elopement; this is not common since, after the act, it requires a good deal of bargaining and personal strength. Second, conceding to an arranged marriage, but combining it with a marakoma relation; lovers' relations are very common and are often a public secret. Marriage by brideprice without sister exchange is a third option. Since access to commodities greatly improved, first by early trading in West Mimika and then by migrant labour, 'left' indirect exchange by brideprice (which allows for more individual choice) has gained in frequency, according to my census data. However, the superior position of the bride-giving party, irrespective of 'right' or 'left' marriage, implies that a married man, especially if young, is at a disadvantage vis-à-vis his bride-givers. This also reflects on his relationship with his wife, the more so since there is no end to a man's obligations to render labour, services and gifts to his bride-givers (though to some extent the bride-givers return the favours). If a married man performs well in fulfilling his obligations, the wife's relatives are reluctant to interfere in domestic arguments, violence, and wife-beating, which do occur. Fairly often, though, interference and beating are a matter of public theatrical performance, rather than reality. I have also observed that wives use the options of withholding their domestic and sexual services, extinguishing the domestic fireplace as a sign of protest, or taking refuge with relatives. Older women are often strong-willed and make a lot of fuss, causing roars of laughter.

Asmat attitudes towards marriage are roughly similar. Asmat women, however, are under the authority of their brothers; brothers are the most important people for any adult person (Eyde 1967:211-303). An unmarried woman could be beaten by her father or her brothers for promiscuity (Eyde 1967:22). The fairly high number of marriages by elopement (worowos) in Zegwaard's 1953 case study of Shuru - 48 out of 102 marriages (Zegwaard and Boelaars 1970:21) - can be interpreted as a way to escape from severe constraints. Marriage by elopement is surely not so common in Mimika, where a woman's choice carries more weight. It is interesting to note that one of the Asmat myths about the mbish, the spirit statues, ascribes its origin to a culture-hero-in-love who carves in wood his beloved wife in order to commemorate her during her absence 
or after her death. ${ }^{27}$ Women are drawn to aggressive men renowned for their fierceness and their success in headhunting. Although a man may marry without having successfully participated in a man-hunt, he may be scolded by his wife as a 'bit of meat' (nas minu), a man without spirit or courage, whenever she gets fed up with him (Zegwaard 1959:1040). It is small wonder then, that, given the preference for male aggression, wife-beating is quite common, without intervention of her brothers (Eyde 1967:192). Marriage by bride-stealing (okore, 'stealing') against her will is reported in Zegwaard's 1952 sample (8 out of 102 marriages, Zegwaard and Boelaars 1970:21). This results in a terrible fight between the two families. Abduction of wives without repayment is described as rampant (Sowada 1961:87). I suspect that bride-stealing was occasionally practised by the Kamoro, but evidence is meagre, and such practices rarely occur in narratives. Marrying women captured in warfare did occur.

An Asmat man is prone to extend his relational network by simultaneous polygyny. This gives him access to women's labour, and to their sago groves, for the benefit of the logistics of warfare and mass food distribution. In Zegwaard's Shuru case study, there were 17 polygynous marriages compared to 59 monogamous ones. The number of wives ranged from two to six. Zegwaard even knows of a 'big man' in Amborep who had 17 wives (Zegwaard and Boelaars 1970:18-9). Second wives 'may be little more than drudges' (Eyde 1967:194). They have no direct access to their husband and are controlled by his first and main wife. So there is some ironic dialectics in women being drawn to aggressive men and polygynous leaders. Polygyny in Mimika is far less frequent and usually restricted to two wives, since the Kamoro female workforce is not connected with endemic warfare and headhunting. On the other hand, at least in one universally known myth, dramatized in Ema Kame ritual, women act as warriors, though dressed up and armed as male combatants - an ambivalent reversal of roles. ${ }^{28}$ The superior 'women of the beginning' rebel against the men who enjoy themselves for ages in the ceremonial nosepiercing house, secretly keeping the delicious food, such as fruits and pieces of fatty meat, for themselves, fobbing the women off with inferior food and having them collect sago and shellfish in a dreary routine. The outraged women wage war, kill a lot of men, abandon them, and depart for the far western part of Mimika, passing over the foothills. They are said to be the ancestresses of white foreigners. The abandoned men initially have to make do with boys and shoots of bamboo impersonating wives, but are then united with anthropomorphic female animals of the forest, the ancestresses of the present race. The superior 'women of the beginning' are lost forever. 
One narrative (see Chapter I) is acted out in a ritual performed to ward off the dreaded danger of men being turned into women and burdened with the care of toddlers, as punishment for not properly looking after a wife who dies in labour. In this ritual, still practised in the 1950s after the death of a woman in labour, male actors, dressed up as the deceased mother and her female assistant, attack a man acting as the careless husband, and his companions. ${ }^{29}$ These two narratives and associated rituals have not been reported for the Asmat. However, Asmat men do consider women who die in labour to be a real threat. Their spirits are known as dambir ow, with frightening looks, a sharp nose, sharp teeth, long nails, and eyes as red as their hair. They take revenge on men by carrying them to the underworld, where they torture them to death with thorns (Sowada 1995a:70).

Extension of Asmat men's relational network by means of papish, that is, establishing bonds between men by institutionalized wife swapping, is discussed in Chapter XI. It does not occur among the Kamoro.

As for acquisition of and control over valued property, Kamoro women clearly have a powerful position. Wild sago groves, in as far as they are collectively owned, belong to specified peraeko, represented in public affairs by an older brother and his real or putative younger brother. However, the female members of the group must be consulted and they have an important say in the exploitation of the groves and in allowing non-members access to these. At home the female head of the household controls the sago bag or sago container: her children must seek her permission and her husband must notify her when they wish to draw on the sago supply. Although a man officially owns the canoe, his wife controls its actual use. Men explain the woman's power over the canoe by pointing out that it is she who uses the canoe to transport the children and mats for roofing, sitting, and sleeping in the temporary huts near fishing and sago grounds. It is mainly a woman's job to pound sago, collect shellfish, and prepare food, but this applies equally to the Asmat. The gear for pounding sago, though partly made by men, is the property of women. Although men own axes and machetes, women have an important say in their use, for they collect and carry wood to burn in the fireplace. A man carrying wood on his back would make a fool of himself. Pandanus trees for matting and other uses are owned by women. They also have control of the many named tidal creeks (enata) fenced off by them, an important source of fish. ${ }^{30}$ Even exclusively male property, such as drums, cannot or at least should not be disposed of without consulting older females.

Information about Asmat female property rights is sketchy. Central Asmat

29 For details of the narrative and the ritual, see Offenberg and Pouwer 2002:148-50, and Pouwer 1987:36-8.

30 For detailed information about property, see Pouwer 1955a:146-51. 
call the husbands, not the wives, the owners (ar arat ow) of sago or fishing areas to which they have gained rights by marriage. Just as a sister is given to her husband, so are her sago paths and fishing areas. ${ }^{31}$ The ceremonial names given to women usually do not derive from their own, but from their husband's kin group. Women could, however, inherit rights to important song cycles. ${ }^{32}$

As for female participation in public affairs and ritual celebrations, Asmat women's part in rituals is not as complementary and integral as among the Kamoro. Among both Kamoro and Asmat, older women can sit in on male public discussions and raise objections.

As for the incidence of female pollution, both Kamoro and Asmat men steer free of menstruating women and women in childbirth, considering these to be women's secrets, ${ }^{33}$ but fear of pollution does not seem to be explicit. Asmat men attribute sorcery exclusively to women (Knauft 1993:101) and 'generally assume that women are hostile to them' (Eyde 1967:147). Kamoro men do not. In both societies, antagonism between the sexes is playfully but aggressively acted out in horseplay (Kamoro: akapa; Asmat: akap, 'laughing, joking'). However, one should distinguish between the horseplay and joking practised by bride-givers and bride-receivers on the one hand, and that between groups of males and females on the other. The latter is named imu by Kamoro as well as Asmat. Both kinds of joking, often going together, are part and parcel of rituals. ${ }^{34}$

\section{Cosmology}

The Kamoro and the Asmat share a dualistic representation of the universe that distinguishes between the complementary opposites of upper world and underworld (Asmat: safan). Its conceptualization is anthropomorphic though not anthropocentric. Humans share life with their natural environment in an intricate system of classifications, differentiated and united by the principle of ipu enakoa, as described by Coenen (1963:22-59, in particular pp. 32-3, 36-9, 43-8). This principle enables its believers to pull the strings of the universe, to manipulate the system of connections between phenomena to their own advantage. They do so in everyday life, for instance in their healing practices, but in particular by means of rituals, as described for the Kamoro in Part One. There is a difference, though, between Kamoro and Asmat: the Kamoro manipulate the system with special emphasis on livelihood, fertility and

Van Arsdale n.y::14; Van Arsdale and Van Arsdale 1991:20, as quoted by Knauft 1993:101.

Pouwer 1955a:174; Eyde 1967:89, 147, as quoted by Knauft 1993:101.

For joking relations among the Kamoro, see Pouwer 1958, 1964. 
health, whereas the Asmat do so specifically for the sake of warfare and selfdefence. This difference corresponds with a difference in cultural orientation, as pointed out in this chapter.

Man-in-his-natural-environment is encircled and encapsulated by the complementary opposites of upper world and underworld. The landscape of the underworld is viewed as similar to the world where humans live, except that the underworld has paradisal abundance and marvellous beaches. The dead are in the underworld, in locations similar to settlements of living humans in the world-in-between. When humans die, their souls travel upstream, follow the foot of the mountains, and descend to the underworld along the pathway of the sun.

The upper world beyond the mountains and the clouds is primarily the seat of the aloof and respectable hero of the sun, Kumurupi (Kamoro) or Anemar Ipic (Zegwaard n.y.c, n.y.d), and addressed - at least by the Kamoro - by the kinship term noopa (grandfather), expressing both respect and familiarity. His bride-receivers, that is, his daughters' and sisters' husbands, the mythical sun people (yao we), live on the borders of the upper world in the far eastern and far western parts of Mimika, on the other side of a wide river and the sea, where the sun sets. The culture hero, carrying the sun as a torch, ascends to and descends from the firmament on the shoulders of his bridereceivers. These move the sun from east to west with ropes (rays), and assist the culture hero when he travels by canoe (or motor car, in a modern version) through the underworld from west to east in order to rise again in the morning. The hero of the sun takes pride of place in Kamoro and Asmat cosmology. In Mimika the sun dance and sun ritual at sunrise mark a sacred moment. The sun dignitary directs wild pigs to the bait. The fish dignitary invokes the sun, addressing him as The Old Man. The sago dignitary asks the sun to shine on sago palms in order to promote growth. In the 'banner' (or 'wing') of the Kamoro and Asmat spirit pole, a round, open hole represents the 'house of the father', the seat of the sun. The hero of the sun is invoked as a solemn witness when lifting food taboos. The sun is said to be the war leader, according to Coenen. After the taboo on drinking water is lifted, young initiates pour out water for the sun. Coenen rightly considers the hero of the sun to be a primus inter pares, rather than a supreme being or high god. A sun cult does not exist (Coenen 1963:83-4; Pouwer 2002:33-4). The hero of the moon, Paotaru (Kamoro) or Manma-tiw-nakap (literally 'the orphan boy', Asmat), also resides in the upper world.

In addition to these beneficial beings, there also live frightful characters in the upper world, such as the two initially terrestrial daughters of the culture hero of the sun, who suspected him of killing their mother and withheld food from him. Heavy wind, rain and thunder are ascribed to these women, as aopao for the exploits of their father (Kamoro version). In the song of the 
clouds (Onam So), performed shortly before Asmat men depart for an attack, a large number of deformed, malevolent and aggressive anthropomorphic or zoomorphic beings are enumerated. They embitter men's life (Zegwaard 1959:1034). Good and bad, like the upper world and the underworld, are complementary opposites. The abode of man-in-nature is an ambivalent betwixtand-between, a corridor, a passageway between the upper and lower worlds. Its heroes have a dual status with respect to the heroes of the universe. Witness the recurrent feature of mythical, terrestrially oriented culture heroes who, as namesakes of upperworld characters, provide the human world with the rotation of the sun and the moon, with rivers, sago, fire, hunting dogs, Western commodities, and iron tools, all associated with the sun and acquired, often by deceit or by accident, from an oblivious upper world or spirits associated with it. ${ }^{35}$ Witness also the tricky acquisition from the underworld of a ceremonial house, yew mopan (Asmat) or kaware (Kamoro), with its astonishing set of paraphernalia, adornments, and garden produce. ${ }^{36}$ In these respects, earthbound heroes and tricksters are clearly superior to their ignorant namesakes in both the upper and the lower worlds. The rotation of the sun is an invention of the terrestrial trickster, not of its upperworld owner. Likewise, the rotation of the moon is ascribed in Kamoro and Asmat versions of the moon myth to a terrestrial orphan boy who, neglected and distrusted by his relatives, discovers the moon in a basket while stealing food (Kamoro), or creates the moon himself (Asmat), and then takes it to the firmament. ${ }^{37}$ Another Kamoro version ascribes the discovery of the moon to illicit terrestrial behaviour of a sister's son towards his mother's brother (Offenberg and Pouwer 2002:78-80). The underworld proprietor of the ceremonial house and its attributes behaves in the Asmat version as a dummy; he rates as an inferior, unfinished male. The Asmat tend to ascribe the 'furnishing' of the human world to mere imitation of superior examples furnished by upperworld heroes. ${ }^{38}$ The in-between situation of the human abode in a spatial sense is graphically expressed by a striking metaphor which David Eyde came across by chance and communicated to the linguist Voorhoeve:

the territory they inhabit, the Asmat capinmi, is enclosed within, and lies at the bottom of, a gigantic coconut: their world is not convex but concave. The boundaries of their world correspond roughly to those of their language area: between the Casuarinen Coast and the Mimika Coast. And one can do the 'journey round the world' by setting out from the Casuarinen Coast, landing there, and then returning [overland] to the Casuarinen Coast. Through the middle of this world flows

See Chapter III, and see the narratives in Offenberg and Pouwer 2002:98-108.

Pouwer 2002:34-6; Offenberg and Pouwer 2002:76-8.

For an example, see Offenberg and Pouwer 2002:108-11. 
the great River Sirec, rising far away, somewhere at the top of the coconut, close to the holy entrance to the upper world. From this opening, in prehistoric times the heavenly beings descended to earth, in order to populate the world with their descendants. (Voorhoeve 1965:3.)

Such a 'heavenly being' is Baitshepsimit (literally the big Baitshep), an enormous androgynous pig, the size of a cow, reared by Manifuk, a supernatural being who lives in the upper world above the clouds on top of the mountains. There is a striking parallel with the primeval pig of the Yali people, a Dani exonym of their highland neighbours east of the Grand (Baliem) Valley. In versions of a central myth, specified rivers, sacred men's houses, and men themselves divided into clans, emerged from a partition of the huge pig at her own request by her son, or were shot by another male culture hero (Zöllner 1988:19, 173-4).

The central Asmat mythical pig has many children: Naneu and Kamkai born from the uterus, Kayir, Kaimes, Yepem, Owus, Sunu and Yaun born from her side or thigh; Ewer, her future son-in-law, is also born from her side or thigh. These are the founders of the yew of Island River and Flamingo Bay, named after them, the Bismam people. One day Ewer, the son-in-law, mistakes his father-in-law for a wild pig, shoots at him in vain, and runs him (or her) down, a capital though unwitting offence. Baitshep removes taro plants and liana and creeps into the hole beneath. He crashes down and down and arrives on the earth near the source of the Island River (Sirec). The noise of the 'earthquake' frightens a number of named, dismal, deformed, inferior men who thereafter stay behind in the upper world. [Compare this to the dismal daughters of the hero of the sun in the Kamoro version and the malevolent anti-human beings in the Asmat ritual song of the clouds.] Below, Baitshep meets Kaimes and Yepem, two of his sons. His other sons, in the upper world, follow his trail, remove the taro and liana put back by him, enter the hole, and are united with their father. Since the huge androgynous pig is far too heavy to climb back to the upper world, the party decide to move on downstream. They settle there. Baitshep teaches them how to attack their enemies, the people already living there: he bares his teeth and growls, and this has been imitated by his descendants during attacks ever since. He teaches his sons to beat the water with their paddles, creating big waves shaped like Baitshep's tusks so that the enemies' canoes will capsize. Baitshep ever since has accompanied them, hanging upside down from the stern of the canoe, his head and tusks facing forwards, thus adding to the size of the waves. ${ }^{39}$ The details of this story are characteristic of the aggressive, headhunting stance of the Asmat 
invaders, whose ancestors - in view of the pig parallel - seem to originate from the highlands.

The Sirec River connects the upper world with the sea. The sea is sometimes represented as a mere tributary of the Sirec, so that one can travel full circle through the human world, and return to its headwaters.

It seems significant that narratives about the origin of named ancestors of localized descent groups are lacking among the Kamoro. Their great trek from southwest to northeast, begun by the warlords and culture heroes Aoweyao and Mbiminareyao, was made by localized descent groups and descent groups not named after ancestors.

All Kamoro and Asmat narratives have one outstanding feature in common: the route of the human (or superhuman) creative beings to and from the upper world and underworld is not paved by good intentions but by anti-social behaviour, such as adultery, incest, theft, suspicion of murder, lack of respect, destruction or loss of property, excessive requests, or failing badly in reciprocity. It is this anti-social behaviour, committed either by them or by their fellow men, which drives them out and forces them to discover other spheres and cultural valuables crucial to human life. Again, in Asmat and Kamoro cosmology, good and evil are complementary. 